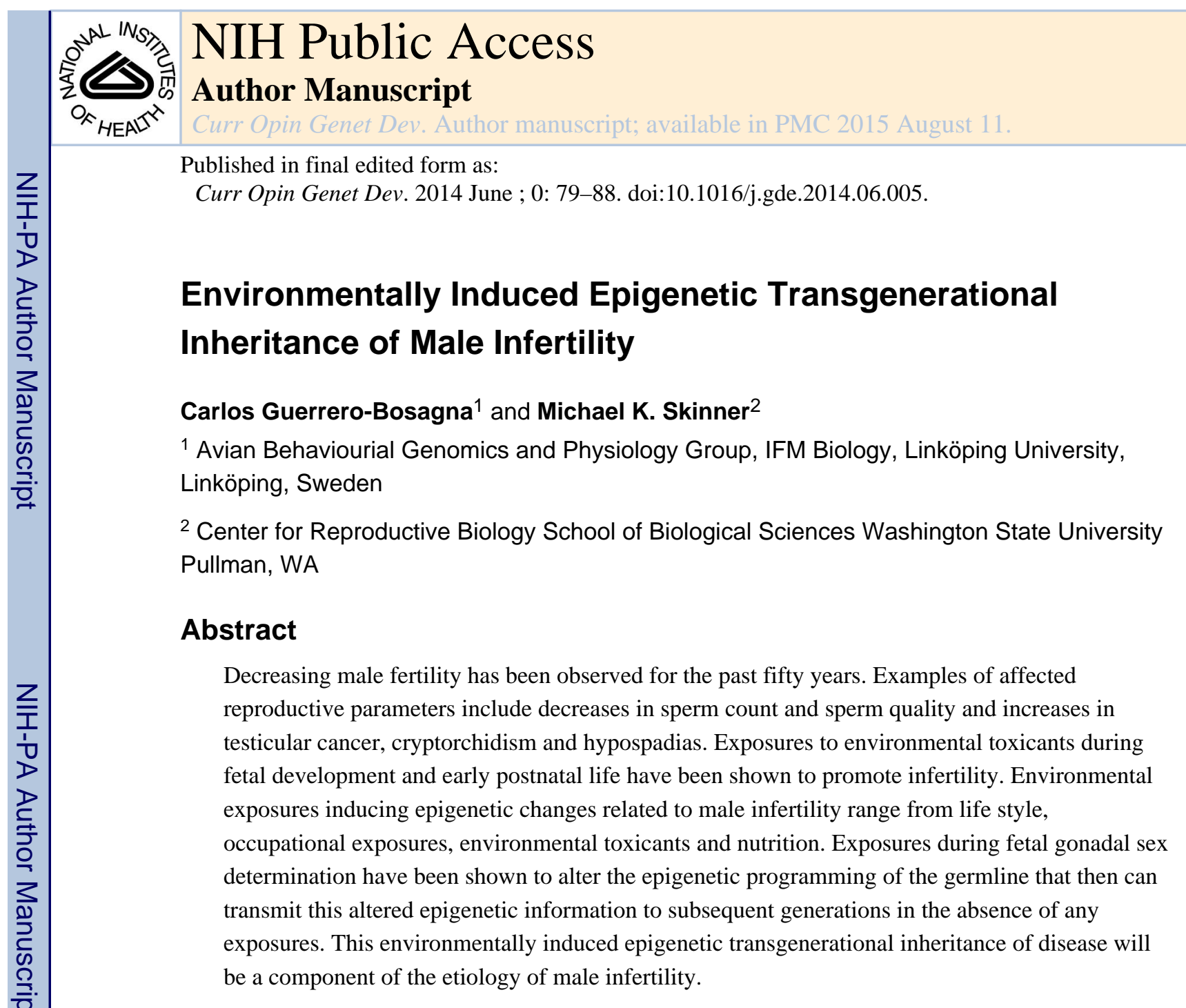

\title{
Introduction
}

Trends have been observed in human populations showing decreasing male fertility for decades [1-4]. Examples of the reproductive parameters effected are decreases in sperm count and quality [2], increases in testicular cancer [3] and increases in cryptorchidism or hypospadias [1]. Data of particular interest include several meta-analysis suggesting a strong decline in sperm quality from the 1940's to present [5-8]. Similar to the phenotypes associated with the metabolic disease syndrome [9], it has been postulated that these male reproductive disorders have a common developmental origin and are physiologically linked, leading to a complex disease trait of 'Testicular Dysgenesis Syndrome' (TDS) [10-12]. The syndrome describes these male reproductive disorders as sharing the same pathophysiological etiology and as being caused by disrupted testicular development in the early fetus $[12,13]$. Interestingly, one of the key studies that documented the recent decrease in

(C) 2014 Elsevier Ltd. All rights reserved.

Correspondence: Michael K. Skinner Center for Reproductive Biology School of Biological Sciences Washington State University Pullman, WA 99164-4236 Phone: 509-335-1524 Fax: 509-335-2176 skinner@wsu.edu.

Publisher's Disclaimer: This is a PDF file of an unedited manuscript that has been accepted for publication. As a service to our customers we are providing this early version of the manuscript. The manuscript will undergo copyediting, typesetting, and review of the resulting proof before it is published in its final citable form. Please note that during the production process errors may be discovered which could affect the content, and all legal disclaimers that apply to the journal pertain. 
sperm quality in men [5] concludes that "Such remarkable changes in semen quality and the occurrence of genitourinary abnormalities over a relative short period is more probably due to environmental rather than genetic factors", an opinion that is supported by more recent publications $[2,11,13]$. This highlights the importance that environmental exposures have on the development of phenotypes associated with fertility in human populations. The vast majority of environmental exposures do not have the capacity to alter the DNA sequence such that classic genetics has difficulty providing a molecular mechanism for the early life exposure effects on later life male fertility [14]. Environmental epigenetics appears to be the molecular mechanism involved [14]. The current review will describe epigenetic mechanisms for the etiology of male infertility that can be dramatically influenced by the environment [15]. The roles of epigenetics versus genetics in environmentally induced male infertility will be reviewed, as well as the generational impacts of environmental epigenetics. Therefore, one of the primary questions addressed is the potential role of epigenetics versus genetics in the etiology of male infertility.

Recent studies demonstrate that exposure to environmental factors such as toxicants, stress or dietary compounds early during development have a significant impact on human health [16-18]. In particular, the male reproductive system appears to be especially sensitive to environmental exposures [13]. It is becoming obvious that phenotypes associated with TDS are related to early developmental environmental exposures $[2,11,13]$ and particularly to exposure to endocrine disrupting chemicals [13, 19]. Early developmental exposures that are reported to be associated with impairment in reproductive function in men include pesticides [20, 21], phthalates [22, 23], analgesics [24], smoking [25, 26] and alcohol [27]. In addition to these common exposures, industrial exposures of men to toxicants have also been reported. For example, in Taiwan accidental in utero exposures of men to the synthetic organic pollutants polychlorinated biphenyl (PCB) and PCDF was reported to produce a marked effect in semen quality and motility later in adulthood [28, 29]. Other examples exist in which agro-workers were exposed to high amounts of the nematicide 1,2-Dibromo-3chloropropane (DBCP) and produced induced sterilization in California during the 1970's [30] and in Costa Rica from early 1960's to 1984 [31].

Fertility rates in both developing and industrialized countries have shown progressive reductions in recent years [32]. Although this trend is certainly partially attributed to government policies together with social, economic and cultural changes, the impact environmental exposures have on impairments in the male reproductive system will be significant. The increasing association of environmental exposures with the incidence of disease [33] support the assumption that human fertility problems are strongly impacted by environmental exposures.

Recently, several studies have described genetic abnormalities associated with decreases in male reproductive parameters. A study found specific genetic abnormalities in $24 \%$ of men with oligozoospermia and azoospermia [34]. Genetic abnormalities related to infertility or subfertility include sex chromosomal aneuploidies, mutations in the cystic fibrosis transmembrane receptor $(\mathrm{Cftr})$ gene or deletion of the AZFc region of the $\mathrm{Y}$ chromosome $[34,35]$. Several gene polymorphisms have also been described to date that associate with reduced male reproductive parameters. A polymorphism in the FSH beta subunit promoter 
region was shown to be associated with low FSH levels, sperm counts and testis volume [36] In both mice and rats the deletion of Fkbp6 (FK506 binding protein 6, 36kDa), which is involved in meiotic pairing of homologous chromosomes, is implicated in sterility in male animals [37]. Recent conditional knock out experiments in mice have shown that adequate levels of PPP1CC2 (protein phosphatase 1, catalytic subunit, gamma isoform 2) are required for normal spermatogenesis and male fertility [38]. Mutations in $\mathrm{Nr} 5 \mathrm{al}$ (nuclear receptor subfamily 5 , group A, member 1 ), which are associated with impaired transactivational activity of this steroidogenic gene have been observed in $4 \%$ of men with severe spermatogenic failure [39]. After initial genome-wide expression screening comparing testis specimens from azoospermic versus normal men, it was found that small nucleotide polymorphisms (SNPs) in the gene Art3 (ADP-ribosyltransferase 3) were associated with both gene expression changes and testosterone levels in patients with azoospermia [40]. A recent genome-wide association study on humans concluded that SNPs associated with candidate genes that correlated with impaired male reproductive parameters [41]. These genes include Ddrl (dopamine receptor D1), Usp8 (ubiquitin specific peptidase 8) and some genes associated with immune processes such as $U b d$ (ubiquitin D), Epstil (epithelial stromal interaction 1) and $\operatorname{Lrc} 32$ (leucine rich repeat containing 32) [41].

Another recent GWAS study assessing loci correlations to non-obstructive azoospermia also found SNPs associated to some genes. These genes correspond to Prmt6 (protein arginine methyltransferase 6), Pex10 (peroxisomal biogenesis factor 10), Sox5 (SRY sex determining region Y-box 5) and Sirpa-Sirpg (signal-regulatory protein alpha and gamma) [42]. The first genome-wide association study for idiopathic male fertility [43] and a follow up study from the same group have identified several SNPs with significant associations to azoospermia and oligozoospermia in men [44]. The most significant associations identified correspond to SNP related to the genes Slc6al4 (solute carrier family 6 (amino acid transporter), member 14), Insr (insulin receptor), Or3w3 (odorant receptor 3), Tas $2 r 38$ (taste receptor, type 2, member 38), Tex15 (testis expressed 15), Faslg (Fas ligand), Brdt (bromodomain, testisspecific) and Jmjdla (Protein JMJD) [44]. Although these SNPs have been identified, the correlation with male fertility in the diseased population of specific SNPs is generally less than $1 \%$ of the diseased population. Genetic mutations will be important, but observations suggest other mechanisms will be involved.

\section{Infertility and Epigenetics}

The genetic background is essentially static in populations where increases in male disorders are occurring. Therefore, ancestral and/or early life exposures to environmental toxicants through environmental epigenetics [14] may be fundamental for the etiology of the disease [45]. In contrast to the low DNA sequence variation observed between humans, extensive natural sperm epigenome variation exists between healthy men [46]. Therefore, correlation of environmental exposures with epigenetic variation in germ cells is critical in order to address fertility issues in humans [47]. Several studies have documented epigenetic disruption related to the incidence of different types of germ cell tumors [48] or related to impaired fertility and spermatogenesis [49]. Indeed, sperm DNA of infertile men display abnormal histone marks (e.g. H3K4me and H3K27me) [50, 51] and also abnormal DNA methylation at imprinted and developmental loci [50-55]. Genome-wide changes in histone 
marks during spermiogenesis would alter chromatin packaging of the sperm DNA and generate poor reproductive outcomes [50,56]. For DNA methylation the changes associated with infertility also appear to be widespread in the sperm genome, including alterations in imprinted and non-imprinted genes [57]. Moreover, it is speculated that altered DNA methylation patterns in imprinted genes would generate imprinting abnormalities in the offspring when this sperm is used in Assisted Reproductive Technologies (ART) [52, 53].

Epigenetic modifications in the germline of either humans or rodents that are associated with infertility include DNA methylation changes in the Mthfr (methylenetetrahydrofolate reductase) promoter region [58], hypomethylation in regions of the imprinted IGF2-H19 locus [53-55, 59], hypermethylation in the imprinted genes Mest [51, 54], Lit1 (Protein LIT-1), Snrpn (small nuclear ribonucleoprotein N), Peg3 (paternally expressed 3) and Zac (ADP-ribosylation factor GTPase-activating protein AGD12) [51], and altered methylation in several other imprinted and non-imprinted genes such as Hras (Harvey rat sarcoma viral oncogene homolog), Nt3 (3'-nucleotidase), Mtla (metallothionein 1A), Pax8 (paired box 8), Diras3 (DIRAS family, GTP-binding RAS-like 3), Plagll(pleiomorphic adenoma gene-like 1), Sfn (stratifin) and Sat2chrml (spermidine/spermine N1-acetyltransferase family member 2) [57]. Histone modifications in the sperm DNA associated with infertility include increased $\mathrm{H} 3 \mathrm{~K} 9$ acetylation and $\mathrm{H} 3 \mathrm{~K} 27$ tri-methylation in exons of the $\mathrm{Brdt}$ gene (bromodomain, testis-specific) leading to reduction in its expression [60], reduced $\mathrm{H} 4$ acetylation in spermatids of infertile man with either qualitatively normal or abnormal spermatogenesis [61], loss of de-methylation activity on H3K9 that reduces expression of genes required for histone replacement in spermiogenesis TNP1 (transition protein 1) and PRM1 (protamine 1) [62], and aberrant acetylation of histones (e.g. H4K12ac) in promoters of developmentally important genes that leads to an insufficient sperm chromatin compaction that persist in the zygote [56].

In addition to the importance of epigenetic mechanisms in the germline, epigenetic marks in somatic cells supporting germ cells are also fundamental for fertility. For example, repeat elements such as B1 SINEs (small interspaced repeat element) have been proposed to have a role in transcriptional regulation of testis-specific genes [63]. Genes involved in the pathway of PIWI associated small RNAs (piRNAs), such as Piwil2 (piwi-like RNA-mediated gene silencing 2) and $T d r d l$ (tudor domain containing 1), are hypermethylated in the testicular tissue of males with different forms of fertility problems [64]. In Sertoli cells Rhox5 (reproductive homeobox 5) gene deletion associates with repression of DNA methylation in two promoters increasing germ-cell apoptosis and decreasing sperm count and motility [65]. Sertoli cell microRNAs have been shown to be involved in the spermiation failure induced by androgen and FSH (follicle stimulating hormone) suppression [66]. Ablation of Dicer (an RNase III endonuclease essential for microRNA processing) in Sertoli cells leads to infertility with a complete absence of spermatozoa and testis degeneration [67]. Dicer is also essential in the testis for the haploid differentiation of the germ cells [68].

The importance of the role of epigenetic mechanisms for infertility is related to the fact that many environmental insults can induce epigenetic alterations. Several examples of environmentally induced developmental effects associated with decreased fertility parameters exist. For example, in utero exposure to phthalates induces a variety of 
abnormalities in the reproductive tract of adult males which resemble the pathophysiological features of Testis Dysgenesis Syndrome [69]. Similar effects are reported with in utero exposures to vinclozolin [18, 70], bisphenol A (BPA) and diethylstilbestrol [71]. Although the majority of these examples do not include assessment of modifications in epigenetic mechanisms, the persistence throughout life of the effects induced during development suggests that epigenetic mechanisms are involved.

In addition to these developmentally induced effects, examples of epigenetic modifications that are environmentally induced and associate with male infertility exist. For instance, exposure of adult male rats to different doses of butyl-paraben [72] and exposure of adult male mice to methoxychlor [73, 74] have been shown to alter DNA methylation in sperm. Neonatal exposure to BPA is detrimental to spermatogenesis and has been shown to alter DNA methylation of the IGF2-H19 imprinting control region in sperm [75] and of the estrogen receptors alpha and beta in testis [76]. Prenatal exposure to ethanol has been shown to induce decreased spermatogenesis and sperm DNA methylation changes in imprinted genes [77]. Different laboratories have shown that an early developmental exposure to the fungicide vinclozolin increases spermatogenic cell apoptosis and alters sperm DNA methylation [74, 78-81]. Interestingly, vinclozolin-induced effects are observed to be transgenerationally transmitted $[74,78,79,81-83]$ through a process known as epigenetic transgenerational inheritance, which will be discussed next in more depth. The germ line consequences of environmental exposure might not only stay at the epigenetic level but is able to induce genomic rearrangements [84].

In spite of these interesting epigenetic effects observed in the germline, the majority of environmentally induced epigenetic changes related to infertility are described in somatic cells supporting spermatogenesis, such as Sertoli and Leydig cells (Figure 1). Changes in DNA methylation have been observed in mouse Leydig TM3 cell line cultures following exposure to either low or high doses of arsenic [3]. Exposure of these cells to cadmium leads to reduced expression of DNA methyltransferase 1 [85]. In utero exposure to di-(2ethylhexyl)phthalate (DEHP) has been shown to produce postnatal alteration in demethylation in several nuclear receptor genes in Leydig cells, among them the estrogen receptor beta, thyroid receptor beta, peroxisome proliferator activated receptor alpha (Pparalpha) and the mineralocorticoid receptor [69]. Not only environmental insults but also natural hormones have the ability to induce epigenetic changes. For example, epigenetic changes are produced in the proximal promoter of the Faah gene (reduced DNA and histone H3 methylation) in response to estradiol in mouse Sertoli cell cultures [86] and treatment of Leydig cells with luteinizing hormone causes hypomethylation [87]. This hormonal regulation of DNA methylation suggests that epigenetic effects in testicular cells derived from environmental exposures are mediated by hormone actions [87].

\section{Male Fertility and Epigenetic Transgenerational Inheritance}

Environmentally induced epigenetic transgenerational inheritance is defined as early developmental exposures that promote altered epigenetic programming in the germline that then transmits altered epigenetic marks to subsequent generations in the absence of environmental exposures $[14,18]$. These epigenetic germline alterations will subsequently 
affect gene expression and epigenetic programming patterns in somatic tissues [15, 88]. This alteration in gene expression contributes to an altered phenotype that is observed generation after generation in a lineage [14, 18] (Figure 1). The first example of an environmentallyinduced epigenetic transgenerational inheritance process was described in 2005 using an early developmental exposure to the endocrine disruptor vinclozolin [74]. Vinclozolin is an agricultural fungicide with anti-androgenic activity widely used in fruit and vegetable crops around the world [89]. A developmental exposure to vinclozolin produced increased apoptosis in spermatogenic cells in rats, which was observed four generations after this initial exposure $[74,82,83]$ (Figure 1). The mechanism involved in the transgenerational transmission of these altered phenotypes was an induced alteration in the sperm epigenome, which was observed three generations after the developmental exposure to vinclozolin [74, $78,79]$. Transgenerational DNA methylation alterations in imprinted genes in sperm have also been reported due to a developmental exposure to vinclozolin [81]. Early developmental exposure to di-(2-thylhexyl) phthalate has also been shown to induce transgenerational effects related to impairment of male fertility, including disruption of testicular germ cell association, reduced sperm count and decreased sperm motility [90]. Other studies have focused on exposures after birth. Perinatal exposure to BPA impairs fertility and spermatogenesis [91] and induces transgenerational alterations in the expression of steroid receptors and their co-regulators in testis [92]. Exposure of 6-week old mice to oral administrations of benzo(a)pyrene induced impairment in several parameters associated with male fertility up to the F2 generation, including testicular malformations, reduced number of seminiferous tubes with elongated spermatids and decreased sperm count [93].

In addition to increased apoptosis in spermatogenic cells, other phenotypes are transmitted through the process of epigenetic transgenerational inheritance. These phenotypes include obesity [94-98], abnormalities of the female reproductive system [78, 88, 97-103], kidney diseases [82, 100, 103], prostate diseases [82], pubertal abnormalities [97, 101-103] and increased incidence of tumors [82].

Environmentally induced epigenetic transgenerational inheritance of disease and sperm altered DNA methylation (epimutations) have been observed with plastic compounds (BPA and phthalates) [97], hydrocarbons (jet fuel JP8) [98], dioxin [99, 103], pesticides (permethrin and DEET) [102], DDT [95], tributyltin [104], and nutrition abnormalities [94, 96]. Epigenetic transgenerational inheritance has also been observed in plants [105], flies [106], worms [107], rodents [74] and humans [108]. Therefore, the epigenetic transgenerational inheritance of disease and male testis abnormalities has been observed with a number of environmental exposures and species [18, 101].

\section{Physiological and Molecular Mechanisms involved in Epigenetic Transgenerational Inheritance}

In order for a transgenerational effect to be produced it is fundamental that the germline epigenome is altered, because it is the germline epigenome that will be transmitted to future generations [18]. The most sensitive period when the germline epigenome can be affected is a major event of epigenetic reprogramming that occurs during primordial germ cell development and initiation of the sex specific germline development. In this period a DNA 
methylation erasure occurs followed by the initiation of re-establishment of DNA methylation patterns $[109,110]$. The erasure of DNA methylation occurs when primordial germ cells migrate to the genital ridge and gonads. Re-methylation is initiated during the first events of sex determination [111,112]. This period in germ cell development and epigenetic programming represents a window of sensitivity to environmental factors [18, 113]. Exposure to environmental compounds induces an altered epigenetic programming during these early developmental stages and the altered epigenome can be perpetuated across generations $[18,74,79]$. Experimental evidence of this window of sensitivity involving the sex determination period exists for vinclozolin and a number of other exposures. For example, the pattern of gene expression is altered in the rat embryonic testis after a maternal exposure to vinclozolin while the embryo is undergoing sex determination $[114,115]$. Interestingly, embryonic testis gene expression is consistently altered in the next generations [116]. Further analysis of vinclozolin-induced transgenerational transcriptome and epigenomic alterations in primordial germ cells in rats (E13 and E16) have been performed [117]. Although the vinclozolin-induced epigenetic and gene expression alterations in primordial germ cells are distinct between these two stages, the cellular processes affected seem to be the same and the effects are more pronounced in E13 (period of maximum erasure of DNA methylation) than in E16 [117].

Environmentally-induced reprogramming of the germline epigenome will induce epigenomic changes in somatic cells [18], as seen in granulosa cells [88] and Sertoli cells [15] using the transgenerational vinclozolin model. Sertoli cells in F3 generation vinclozolin lineage males were found to have a transgenerational epigenome and transcriptome that correlated with the spermatogenic cell apoptosis phenotype observed [15]. Analysis of the transgenerational transcriptome revealed a large number of differentially regulated and reduced gene expression was in the pyruvate synthesis and degradation pathway [15]. Since pyruvate is an essential energy metabolite provided by Sertoli cells and required for spermatogenic cells, the transgenerational testis phenotype appears to be in part due to abnormal Sertoli cell function [15] (Figure 1).

A general misconception exists that the epigenome changes observed in the germline should be the same as the ones observed in somatic cells. Although the environmentally induced epigenetic changes will influence the developing epigenomes seen in somatic cells, they are not necessarily the same due to the dramatic epigenetic programming required for somatic cell differentiation [14]. In the same line, the derived epigenomic somatic changes will influence gene expression changes in that tissue but not necessarily in the same genes (Figure 2). What has been observed using the vinclozolin model is that transgenerational environmentally induced epigenome changes in somatic tissues will affect the gene expression of many genes in a tissue and cell specific manner $[15,88]$. This phenomenon can be due to long distance regulation of clusters of gene expression through epigenetic control regions $[101,118]$.

\section{Conclusion}

Epigenetic transgenerational Inheritance is a phenomenon to be considered in disease etiology, reproduction and human fertility. Clearly, considering only genetic mutations 
cannot completely explain disease etiology. Environmental exposures and related epigenetic changes are equally important for consideration. Interestingly, these environmental exposures can influence the future generations' susceptibility for disease, particularly disease related to reproduction. Future studies will need to focus on identifying these epigenetic alterations and epigenetic biomarkers to understand the epigenetic mechanisms that mediate environmental exposures and impairment of fertility. These investigations will provide important information to develop novel diagnostics and therapeutics for the treatment of male infertility.

In considering the relative roles of epigenetics and genetics in the etiology of male infertility, as well as nearly all disease, environmental epigenetics is a critical factor to consider. However, epigenetics does not act in isolation and depends on the genetic background. The epigenetics works through altering genome activity. Therefore genetics and epigenetics are integrated to a point that few epigenetic only events and genetic only events will exist. These two integrated processes directly influence the etiology of disease. What epigenetics provides is a conduit for the environment to alter directly genome activity and provides a mechanism for early life or ancestral exposures to impact adult onset disease such as male infertility.

\section{References}

\section{** References of outstanding interest}

\section{* References of special interest}

1. Main KM, Skakkebaek NE, Virtanen HE, Toppari J. Genital anomalies in boys and the environment. Best Pract Res Clin Endocrinol Metab. 2010; 24:279-289. [PubMed: 20541152]

2**. Sharpe RM. Environmental/lifestyle effects on spermatogenesis. Philos Trans R Soc Lond B Biol Sci. 2010; 365:1697-1712. [PubMed: 20403879] [Critical review of the decline in male fertility and correlated environmental exposures.]

3. Skakkebaek NE, Rajpert-De Meyts E, Jorgensen N, Main KM, Leffers H, Andersson AM, Juul A, Jensen TK, Toppari J. Testicular cancer trends as 'whistle blowers' of testicular developmental problems in populations. Int J Androl. 2007; 30:198-204. discussion 204-195. [PubMed: 17705804]

4. Andersson AM, Jorgensen N, Main KM, Toppari J, Rajpert-De Meyts E, Leffers H, Juul A, Jensen TK, Skakkebaek NE. Adverse trends in male reproductive health: we may have reached a crucial 'tipping point'. Int J Androl. 2008; 31:74-80. [PubMed: 18194282]

5. Carlsen E, Giwercman A, Keiding N, Skakkebaek NE. Evidence for decreasing quality of semen during past 50 years. BMJ. 1992; 305:609-613. [PubMed: 1393072]

6. Merzenich H, Zeeb H, Blettner M. Decreasing sperm quality: a global problem? BMC Public Health. 2010; 10:24. [PubMed: 20085639]

7. Swan SH, Elkin EP, Fenster L. Have sperm densities declined? A reanalysis of global trend data. Environ Health Perspect. 1997; 105:1228-1232. [PubMed: 9370524]

8. Swan SH, Elkin EP, Fenster L. The question of declining sperm density revisited: an analysis of 101 studies published 1934-1996. Environ Health Perspect. 2000; 108:961-966. [PubMed: 11049816]

9. Brenseke B, Prater MR, Bahamonde J, Gutierrez JC. Current thoughts on maternal nutrition and fetal programming of the metabolic syndrome. J Pregnancy. 2013; 2013:368461. [PubMed: 23476780]

10. Skakkebaek NE, Rajpert-De Meyts E, Main KM. Testicular dysgenesis syndrome: an increasingly common developmental disorder with environmental aspects. Hum Reprod. 2001; 16:972-978. [PubMed: 11331648] 
11*. Giwercman A, Giwercman YL. Environmental factors and testicular function. Best Pract Res Clin Endocrinol Metab. 2011; 25:391-402. [PubMed: 21397206] [Critical review of the link of early life exposures and testis disease and abnormalities.]

12. Wohlfahrt-Veje C, Main KM, Skakkebaek NE. Testicular dysgenesis syndrome: foetal origin of adult reproductive problems. Clin Endocrinol. 2009; 71:459-465.

13. Nordkap L, Joensen UN, Blomberg Jensen M, Jorgensen N. Regional differences and temporal trends in male reproductive health disorders: semen quality may be a sensitive marker of environmental exposures. Mol Cell Endocrinol. 2012; 355:221-230. [PubMed: 22138051]

14. Skinner MK. Environmental epigenetic transgenerational inheritance and somatic epigenetic mitotic stability. Epigenetics. 2011; 6:838-842. [PubMed: 21637037]

15. Guerrero-Bosagna C, Savenkova M, Haque MM, Sadler-Riggleman I, Skinner MK. Environmentally Induced Epigenetic Transgenerational Inheritance of Altered Sertoli Cell Transcriptome and Epigenome: Molecular Etiology of Male Infertility. PLoS ONE. 2013; 8:e59922. [PubMed: 23555832]

16**. Guillette LJ Jr. Iguchi T. Ecology. Life in a contaminated world. Science. 2012; 337:1614-1615. [PubMed: 23019638] [Critical perspective of environmental contamination and early life impacts on health and disease, as well as correlation to Rachel Carson book.]

17. Guerrero-Bosagna C, Skinner MK. Environmentally induced epigenetic transgenerational inheritance of phenotype and disease. Mol Cell Endocrinol. 2012; 354:3-8. [PubMed: 22020198]

$18 * *$. Skinner MK, Manikkam M, Guerrero-Bosagna C. Epigenetic transgenerational actions of environmental factors in disease etiology. Trends Endocrinol Metab. 2010; 21:214-222. [PubMed: 20074974] [Critical review of the environmentally induced epigenetic transgenerational inheritance of disease phenomenon.]

19. Bay K, Asklund C, Skakkebaek NE, Andersson AM. Testicular dysgenesis syndrome: possible role of endocrine disrupters. Best Pract Res Clin Endocrinol Metab. 2006; 20:77-90. [PubMed: $16522521]$

20. Damgaard IN, Skakkebaek NE, Toppari J, Virtanen HE, Shen H, Schramm KW, Petersen JH, Jensen TK, Main KM. Persistent pesticides in human breast milk and cryptorchidism. Environ Health Perspect. 2006; 114:1133-1138. [PubMed: 16835070]

21. Andersen HR, Schmidt IM, Grandjean P, Jensen TK, Budtz-Jorgensen E, Kjaerstad MB, Baelum J, Nielsen JB, Skakkebaek NE, Main KM. Impaired reproductive development in sons of women occupationally exposed to pesticides during pregnancy. Environ Health Perspect. 2008; 116:566572. [PubMed: 18414644]

22. Main KM, Mortensen GK, Kaleva MM, Boisen KA, Damgaard IN, Chellakooty M, Schmidt IM, Suomi AM, Virtanen HE, Petersen DV, Andersson AM, Toppari J, Skakkebaek NE. Human breast milk contamination with phthalates and alterations of endogenous reproductive hormones in infants three months of age. Environ Health Perspect. 2006; 114:270-276. [PubMed: 16451866]

23. Swan SH, Main KM, Liu F, Stewart SL, Kruse RL, Calafat AM, Mao CS, Redmon JB, Ternand CL, Sullivan S, Teague JL. Decrease in anogenital distance among male infants with prenatal phthalate exposure. Environ Health Perspect. 2005; 113:1056-1061. [PubMed: 16079079]

24. Kristensen DM, Hass U, Lesne L, Lottrup G, Jacobsen PR, Desdoits-Lethimonier C, Boberg J, Petersen JH, Toppari J, Jensen TK, Brunak S, Skakkebaek NE, Nellemann C, Main KM, Jegou B, Leffers $\mathrm{H}$. Intrauterine exposure to mild analgesics is a risk factor for development of male reproductive disorders in human and rat. Hum Reprod. 2011; 26:235-244. [PubMed: 21059752]

25. Ramlau-Hansen CH, Thulstrup AM, Storgaard L, Toft G, Olsen J, Bonde JP. Is prenatal exposure to tobacco smoking a cause of poor semen quality? A follow-up study. Am J Epidemiol. 2007; 165:1372-1379. [PubMed: 17369608]

26. Ravnborg TL, Jensen TK, Andersson AM, Toppari J, Skakkebaek NE, Jorgensen N. Prenatal and adult exposures to smoking are associated with adverse effects on reproductive hormones, semen quality, final height and body mass index. Hum Reprod. 2011; 26:1000-1011. [PubMed: 21335416]

27. Damgaard IN, Jensen TK, Petersen JH, Skakkebaek NE, Toppari J, Main KM. Cryptorchidism and maternal alcohol consumption during pregnancy. Environ Health Perspect. 2007; 115:272-277. [PubMed: 17384777] 
28. Guo YL, Hsu PC, Hsu CC, Lambert GH. Semen quality after prenatal exposure to polychlorinated biphenyls and dibenzofurans. Lancet. 2000; 356:1240-1241. [PubMed: 11072947]

29. Guo YL, Lambert GH, Hsu CC, Hsu MM. Yucheng: health effects of prenatal exposure to polychlorinated biphenyls and dibenzofurans. Int Arch Occup Environ Health. 2004; 77:153-158. [PubMed: 14963712]

30. Whorton D, Milby TH, Krauss RM, Stubbs HA. Testicular function in DBCP exposed pesticide workers. J Occup Med. 1979; 21:161-166. [PubMed: 556420]

31. Thrupp LA. Sterilization of workers from pesticide exposure: the causes and consequences of DBCP-induced damage in Costa Rica and beyond. Int J Health Serv. 1991; 21:731-757. [PubMed: 1769760]

32**. Skakkebaek NE, Jorgensen N, Main KM, Rajpert-De Meyts E, Leffers H, Andersson AM, Juul A, Carlsen E, Mortensen GK, Jensen TK, Toppari J. Is human fecundity declining? Int J Androl. 2006; 29:2-11. [PubMed: 16466518] [Critical review of the decline in male fertility and correlation with environmental exposures, as well as need for collaborative programs.]

33. Pimentel D, Cooperstein S, Randell H, Filiberto D, Sorrentino S, Kaye B, Nicklin C, Yagi J, Brian J, O'Hern J, Habas A, Weinstein1 C. Ecology of Increasing Diseases: Population Growth and Environmental Degradation. Human Ecology. 2007; 35:653-668.

34. Dohle GR, Halley DJ, Van Hemel JO, van den Ouwel AM, Pieters MH, Weber RF, Govaerts LC. Genetic risk factors in infertile men with severe oligozoospermia and azoospermia. Hum Reprod. 2002; 17:13-16. [PubMed: 11756355]

35. Huynh T, Mollard R, Trounson A. Selected genetic factors associated with male infertility. Hum Reprod Update. 2002; 8:183-198. [PubMed: 12099633]

36. Grigorova M, Punab M, Ausmees K, Laan M. FSHB promoter polymorphism within evolutionary conserved element is associated with serum FSH level in men. Hum Reprod. 2008; 23:2160-2166. [PubMed: 18567894]

37. Crackower MA, Kolas NK, Noguchi J, Sarao R, Kikuchi K, Kaneko H, Kobayashi E, Kawai Y, Kozieradzki I, Landers R, Mo R, Hui CC, Nieves E, Cohen PE, Osborne LR, Wada T, Kunieda T, Moens PB, Penninger JM. Essential role of Fkbp6 in male fertility and homologous chromosome pairing in meiosis. Science. 2003; 300:1291-1295. [PubMed: 12764197]

38. Sinha N, Puri P, Nairn AC, Vijayaraghavan S. Selective Ablation of Ppplcc Gene in Testicular Germ Cells Causes Oligo-Teratozoospermia and Infertility in Mice. Biol Reprod. 2013 (Epub ahead of print).

39. Bashamboo A, Ferraz-de-Souza B, Lourenco D, Lin L, Sebire NJ, Montjean D, Bignon-Topalovic J, Mandelbaum J, Siffroi JP, Christin-Maitre S, Radhakrishna U, Rouba H, Ravel C, Seeler J, Achermann JC, McElreavey K. Human male infertility associated with mutations in NR5A1 encoding steroidogenic factor 1. Am J Hum Genet. 2010; 87:505-512. [PubMed: 20887963]

40. Okada H, Tajima A, Shichiri K, Tanaka A, Tanaka K, Inoue I. Genome-wide expression of azoospermia testes demonstrates a specific profile and implicates ART3 in genetic susceptibility. PLoS Genet. 2008; 4:e26. [PubMed: 18266473]

41. Kosova G, Scott NM, Niederberger C, Prins GS, Ober C. Genome-wide association study identifies candidate genes for male fertility traits in humans. Am J Hum Genet. 2012; 90:950-961. [PubMed: 22633400]

42. Hu Z, Xia Y, Guo X, Dai J, Li H, Hu H, Jiang Y, Lu F, Wu Y, Yang X, Yao B, Lu C, Xiong C, Li Z, Gui Y, Liu J, Zhou Z, Shen H, Wang X, Sha J. A genome-wide association study in Chinese men identifies three risk loci for non-obstructive azoospermia. Nat Genet. 2012; 44:183-186. [PubMed: 22197933]

43. Aston KI, Carrell DT. Genome-wide study of single-nucleotide polymorphisms associated with azoospermia and severe oligozoospermia. J Androl. 2009; 30:711-725. [PubMed: 19478329]

44*. Aston KI, Krausz C, Laface I, Ruiz-Castane E, Carrell DT. Evaluation of 172 candidate polymorphisms for association with oligozoospermia or azoospermia in a large cohort of men of European descent. Hum Reprod. 2010; 25:1383-1397. [PubMed: 20378615] [Critical genome wide association study (GWAS) and correlation with male infertility.] 
45. Hughes IA, Martin H, Jaaskelainen J. Genetic mechanisms of fetal male undermasculinization: a background to the role of endocrine disruptors. Environ Res. 2006; 100:44-49. [PubMed: 16271714]

46. Flanagan JM, Popendikyte V, Pozdniakovaite N, Sobolev M, Assadzadeh A, Schumacher A, Zangeneh M, Lau L, Virtanen C, Wang SC, Petronis A. Intra- and interindividual epigenetic variation in human germ cells. Am J Hum Genet. 2006; 79:67-84. [PubMed: 16773567]

47. Guerrero-Bosagna C, Skinner M. Environmental epigenetics and effects on male fertility. Advances in experimental medicine and biology. 2014:67-81. [PubMed: 23955673]

48. Oosterhuis JW, Looijenga LH. Testicular germ-cell tumours in a broader perspective. Nat Rev Cancer. 2005; 5:210-222. [PubMed: 15738984]

49. Rajender S, Avery K, Agarwal A. Epigenetics, spermatogenesis and male infertility. Mutat Res. 2011; 727:62-71. [PubMed: 21540125]

50. Hammoud SS, Nix DA, Hammoud AO, Gibson M, Cairns BR, Carrell DT. Genome-wide analysis identifies changes in histone retention and epigenetic modifications at developmental and imprinted gene loci in the sperm of infertile men. Hum Reprod. 2011; 26:2558-2569. [PubMed: 21685136]

51. Hammoud SS, Purwar J, Pflueger C, Cairns BR, Carrell DT. Alterations in sperm DNA methylation patterns at imprinted loci in two classes of infertility. Fertil Steril. 2010; 94:17281733. [PubMed: 19880108]

52. Kobayashi H, Sato A, Otsu E, Hiura H, Tomatsu C, Utsunomiya T, Sasaki H, Yaegashi N, Arima T. Aberrant DNA methylation of imprinted loci in sperm from oligospermic patients. Hum Mol Genet. 2007; 16:2542-2551. [PubMed: 17636251]

53. Marques CJ, Carvalho F, Sousa M, Barros A. Genomic imprinting in disruptive spermatogenesis. Lancet. 2004; 363:1700-1702. [PubMed: 15158633]

54. Marques CJ, Costa P, Vaz B, Carvalho F, Fernandes S, Barros A, Sousa M. Abnormal methylation of imprinted genes in human sperm is associated with oligozoospermia. Mol Hum Reprod. 2008; 14:67-74. [PubMed: 18178607]

55. Marques CJ, Francisco T, Sousa S, Carvalho F, Barros A, Sousa M. Methylation defects of imprinted genes in human testicular spermatozoa. Fertil Steril. 2010; 94:585-594. [PubMed: 19338988]

56. Paradowska AS, Miller D, Spiess AN, Vieweg M, Cerna M, Dvorakova-Hortova K, Bartkuhn M, Schuppe HC, Weidner W, Steger K. Genome wide identification of promoter binding sites for H4K12ac in human sperm and its relevance for early embryonic development. Epigenetics. 2012; 7:1057-1070. [PubMed: 22894908]

57*. Houshdaran S, Cortessis VK, Siegmund K, Yang A, Laird PW, Sokol RZ. Widespread epigenetic abnormalities suggest a broad DNA methylation erasure defect in abnormal human sperm. PLoS ONE. 2007; 2:e1289. [PubMed: 18074014] [Human sperm DNA methylation abnormalities correlation with abnormal sperm parameters.]

58. Wu W, Shen O, Qin Y, Niu X, Lu C, Xia Y, Song L, Wang S, Wang X. Idiopathic male infertility is strongly associated with aberrant promoter methylation of methylenetetrahydrofolate reductase (MTHFR). PLoS ONE. 2010; 5:e13884. [PubMed: 21085488]

59. Boissonnas CC, Abdalaoui HE, Haelewyn V, Fauque P, Dupont JM, Gut I, Vaiman D, Jouannet P, Tost J, Jammes H. Specific epigenetic alterations of IGF2-H19 locus in spermatozoa from infertile men. Eur J Hum Genet. 2010; 18:73-80. [PubMed: 19584898]

60. Steilmann C, Cavalcanti MC, Bartkuhn M, Pons-Kuhnemann J, Schuppe HC, Weidner W, Steger $\mathrm{K}$, Paradowska A. The interaction of modified histones with the bromodomain testis-specific (BRDT) gene and its mRNA level in sperm of fertile donors and subfertile men. Reproduction. 2010; 140:435-443. [PubMed: 20538714]

61. Sonnack V, Failing K, Bergmann M, Steger K. Expression of hyperacetylated histone H4 during normal and impaired human spermatogenesis. Andrologia. 2002; 34:384-390. [PubMed: 12472623]

62. Okada Y, Scott G, Ray MK, Mishina Y, Zhang Y. Histone demethylase JHDM2A is critical for Tnp1 and Prm1 transcription and spermatogenesis. Nature. 2007; 450:119-123. [PubMed: 17943087] 
63. Ichiyanagi K, Li Y, Watanabe T, Ichiyanagi T, Fukuda K, Kitayama J, Yamamoto Y, KuramochiMiyagawa S, Nakano T, Yabuta Y, Seki Y, Saitou M, Sasaki H. Locus- and domain-dependent control of DNA methylation at mouse B1 retrotransposons during male germ cell development. Genome Res. 2011; 21:2058-2066. [PubMed: 22042642]

64. Heyn H, Ferreira HJ, Bassas L, Bonache S, Sayols S, Sandoval J, Esteller M, Larriba S. Epigenetic disruption of the PIWI pathway in human spermatogenic disorders. PLoS ONE. 2012; 7:e47892. [PubMed: 23112866]

65. Shanker S, Hu Z, Wilkinson MF. Epigenetic regulation and downstream targets of the Rhox5 homeobox gene. Int J Androl. 2008; 31:462-470. [PubMed: 18637153]

66. Nicholls PK, Harrison CA, Walton KL, McLachlan RI, O'Donnell L, Stanton PG. Hormonal regulation of sertoli cell micro-RNAs at spermiation. Endocrinology. 2011; 152:1670-1683. [PubMed: 21325043]

67. Papaioannou MD, Pitetti JL, Ro S, Park C, Aubry F, Schaad O, Vejnar CE, Kuhne F, Descombes P, Zdobnov EM, McManus MT, Guillou F, Harfe BD, Yan W, Jegou B, Nef S. Sertoli cell Dicer is essential for spermatogenesis in mice. Dev Biol. 2009; 326:250-259. [PubMed: 19071104]

68. Korhonen HM, Meikar O, Yadav RP, Papaioannou MD, Romero Y, Da Ros M, Herrera PL, Toppari J, Nef S, Kotaja N. Dicer is required for haploid male germ cell differentiation in mice. PLoS ONE. 2011; 6:e24821. [PubMed: 21949761]

69. Martinez-Arguelles DB, Campioli E, Culty M, Zirkin BR, Papadopoulos V. Fetal origin of endocrine dysfunction in the adult: The phthalate model. J Steroid Biochem Mol Biol. 2013; 137:5-17. [PubMed: 23333934]

70. Uzumcu M, Suzuki H, Skinner MK. Effect of the anti-androgenic endocrine disruptor vinclozolin on embryonic testis cord formation and postnatal testis development and function. Reprod Toxicol. 2004; 18:765-774. [PubMed: 15279874]

71. LaRocca J, Boyajian A, Brown C, Smith SD, Hixon M. Effects of in utero exposure to Bisphenol A or diethylstilbestrol on the adult male reproductive system. Birth Defects Res B Dev Reprod Toxicol. 2011; 92:526-533. [PubMed: 21922642]

72. Park CJ, Nah WH, Lee JE, Oh YS, Gye MC. Butyl paraben-induced changes in DNA methylation in rat epididymal spermatozoa. Andrologia. 2012; 44(Suppl 1):187-193. [PubMed: 21592178]

73. Stouder C, Paoloni-Giacobino A. Specific transgenerational imprinting effects of the endocrine disruptor methoxychlor on male gametes. Reproduction. 2011; 141:207-216. [PubMed: 21062904]

74**. Anway MD, Cupp AS, Uzumcu M, Skinner MK. Epigenetic transgenerational actions of endocrine disruptors and male fertility. Science. 2005; 308:1466-1469. [PubMed: 15933200] [Initial observation of environmentally induced epigenetic transgenerational inheritance of disease.]

75. Doshi T, D'Souza C, Vanage G. Aberrant DNA methylation at Igf2-H19 imprinting control region in spermatozoa upon neonatal exposure to bisphenol A and its association with post implantation loss. Mol Biol Rep. 2013; 40:4747-4757. [PubMed: 23653003]

76. Doshi T, Mehta SS, Dighe V, Balasinor N, Vanage G. Hypermethylation of estrogen receptor promoter region in adult testis of rats exposed neonatally to bisphenol A. Toxicology. 2011; 289:74-82. [PubMed: 21827818]

77. Stouder C, Somm E, Paoloni-Giacobino A. Prenatal exposure to ethanol: a specific effect on the H19 gene in sperm. Reprod Toxicol. 2011; 31:507-512. [PubMed: 21382472]

78**. Guerrero-Bosagna C, Covert T, Haque MM, Settles M, Nilsson EE, Anway MD, Skinner MK. Epigenetic Transgenerational Inheritance of Vinclozolin Induced Mouse Adult Onset Disease and Associated Sperm Epigenome Biomarkers. Reproductive Toxicology. 2012; 34:694-707. [PubMed: 23041264] [Genome wide promoter analysis of transgenerational DNA methylation abnormalities (epimutations) in sperm.]

79. Guerrero-Bosagna C, Settles M, Lucker B, Skinner M. Epigenetic transgenerational actions of vinclozolin on promoter regions of the sperm epigenome. PLoS ONE. 2010; 5:e13100. [PubMed: 20927350]

80. Lee S-H, Oh T. Genome-wide analysis of epigenetic changes in mouse sperm by maternal exposure to endocrine disruptor vinclozolin. Mol Cell Toxicol. 2012:43-52. 
81. Stouder C, Paoloni-Giacobino A. Transgenerational effects of the endocrine disruptor vinclozolin on the methylation pattern of imprinted genes in the mouse sperm. Reproduction. 2010; 139:373379. [PubMed: 19887539]

82. Anway MD, Leathers C, Skinner MK. Endocrine disruptor vinclozolin induced epigenetic transgenerational adult-onset disease. Endocrinology. 2006; 147:5515-5523. [PubMed: 16973726]

83. Anway MD, Memon MA, Uzumcu M, Skinner MK. Transgenerational effect of the endocrine disruptor vinclozolin on male spermatogenesis. J Androl. 2006; 27:868-879. [PubMed: 16837734]

84. Olsen AK, Andreassen A, Singh R, Wiger R, Duale N, Farmer PB, Brunborg G. Environmental exposure of the mouse germ line: DNA adducts in spermatozoa and formation of de novo mutations during spermatogenesis. PLoS ONE. 2010; 5:e11349. [PubMed: 20596530]

85. Singh KP, Kumari R, Pevey C, Jackson D, DuMond JW. Long duration exposure to cadmium leads to increased cell survival, decreased DNA repair capacity, and genomic instability in mouse testicular Leydig cells. Cancer Lett. 2009; 279:84-92. [PubMed: 19232459]

86. Grimaldi P, Pucci M, Di Siena S, Di Giacomo D, Pirazzi V, Geremia R, Maccarrone M. The faah gene is the first direct target of estrogen in the testis: role of histone demethylase LSD1. Cell Mol Life Sci. 2012; 69:4177-4190. [PubMed: 22802127]

87. Reddy PM, Reddy PR. Differential regulation of DNA methylation in rat testis and its regulation by gonadotropic hormones. J Steroid Biochem. 1990; 35:173-178. [PubMed: 2308334]

88. Nilsson E, Larsen G, Manikkam M, Guerrero-Bosagna C, Savenkova M, Skinner M. Environmentally Induced Epigenetic Transgenerational Inheritance of Ovarian Disease. PLoS ONE. 2012; 7:e36129. [PubMed: 22570695]

89. Wong C, Kelce WR, Sar M, Wilson EM. Androgen receptor antagonist versus agonist activities of the fungicide vinclozolin relative to hydroxyflutamide. J Biol Chem. 1995; 270:19998-20003. [PubMed: 7650017]

90. Doyle TJ, Bowman JL, Windell VL, McLean DJ, Kim KH. Transgenerational Effects of Di-(2ethylhexyl) Phthalate on Testicular Germ Cell Associations and Spermatogonial Stem Cells in Mice. Biol Reprod. 2013; 88:112. [PubMed: 23536373]

91. Salian S, Doshi T, Vanage G. Perinatal exposure of rats to Bisphenol A affects fertility of male offspring--an overview. Reprod Toxicol. 2011; 31:359-362. [PubMed: 20965246]

92. Salian S, Doshi T, Vanage G. Impairment in protein expression profile of testicular steroid receptor coregulators in male rat offspring perinatally exposed to Bisphenol A. Life Sci. 2009; 85:11-18. [PubMed: 19379760]

93. Mohamed el SA, Song WH, Oh SA, Park YJ, You YA, Lee S, Choi JY, Kim YJ, Jo I, Pang MG. The transgenerational impact of benzo(a)pyrene on murine male fertility. Hum Reprod. 2010; 25:2427-2433. [PubMed: 20729536]

94. Dunn GA, Bale TL. Maternal high-fat diet effects on third-generation female body size via the paternal lineage. Endocrinology. 2011; 152:2228-2236. [PubMed: 21447631]

95. Skinner MK, Manikkam M, Tracey R, Nilsson E, Haque MM, Guerrero-Bosagna C. Ancestral DDT Exposures Promote Epigenetic Transgenerational Inheritance of Obesity BMC Medicine. $2013 ; 11: 228$.

96. Waterland RA, Travisano M, Tahiliani KG, Rached MT, Mirza S. Methyl donor supplementation prevents transgenerational amplification of obesity. Int J Obes (Lond). 2008; 32:1373-1379. [PubMed: 18626486]

97. Manikkam M, Tracey R, Guerrero-Bosagna C, Skinner M. Plastics Derived Endocrine Disruptors (BPA, DEHP and DBP) Induce Epigenetic Transgenerational Inheritance of Adult-Onset Disease and Sperm Epimutations. PLoS ONE. 2013; 8:e55387. [PubMed: 23359474]

98. Tracey R, Manikkam M, Guerrero-Bosagna C, Skinner M. Hydrocarbon (Jet Fuel JP-8) Induces Epigenetic Transgenerational Inheritance of Adult-Onset Disease and Sperm Epimutations. Reproductive Toxicology. 2013; 36:104-116. [PubMed: 23453003]

99. Bruner-Tran KL, Osteen KG. Developmental exposure to TCDD reduces fertility and negatively affects pregnancy outcomes across multiple generations. Reprod Toxicol. 2011; 31:344-350. [PubMed: 20955784] 
100. Nilsson EE, Anway MD, Stanfield J, Skinner MK. Transgenerational epigenetic effects of the endocrine disruptor vinclozolin on pregnancies and female adult onset disease. Reproduction. 2008; 135:713-721. [PubMed: 18304984]

101. Manikkam M, Guerrero-Bosagna C, Tracey R, Haque MM, Skinner MK. Transgenerational Actions of Environmental Compounds on Reproductive Disease and Epigenetic Biomarkers of Ancestral Exposures. PLoS ONE. 2012; 7:e31901. [PubMed: 22389676]

102. Manikkam M, Tracey R, Guerrero-Bosagna C, Skinner M. Pesticide and Insect Repellent Mixture (Permethrin and DEET) Induces Epigenetic Transgenerational Inheritance of Disease and Sperm Epimutations. Reproductive Toxicology. 2012; 34:708-719. [PubMed: 22975477]

103. Manikkam M, Tracey R, Guerrero-Bosagna C, Skinner MK. Dioxin (TCDD) induces epigenetic transgenerational inheritance of adult onset disease and sperm epimutations. PLoS ONE. 2012; 7:e46249. [PubMed: 23049995]

104. Chamorro-Garcia R, Sahu M, Abbey RJ, Laude J, Pham N, Blumberg B. Transgenerational inheritance of increased fat depot size, stem cell reprogramming, and hepatic steatosis elicited by prenatal exposure to the obesogen tributyltin in mice. Environ Health Perspect. 2013; 121:359 366. [PubMed: 23322813]

105. Hauser MT, Aufsatz W, Jonak C, Luschnig C. Transgenerational epigenetic inheritance in plants. Biochim Biophys Acta. 2011; 1809:459-468. [PubMed: 21515434]

106. Ruden DM, Lu X. Hsp90 affecting chromatin remodeling might explain transgenerational epigenetic inheritance in Drosophila. Curr Genomics. 2008; 9:500-508. [PubMed: 19506739]

107. Greer EL, Maures TJ, Ucar D, Hauswirth AG, Mancini E, Lim JP, Benayoun BA, Shi Y, Brunet A. Transgenerational epigenetic inheritance of longevity in Caenorhabditis elegans. Nature. 2011; 479:365-371. [PubMed: 22012258]

108. Pembrey ME. Male-line transgenerational responses in humans. Hum Fertil (Camb). 2010; 13:268-271. [PubMed: 21117937]

109. Lees-Murdock DJ, Walsh CP. DNA methylation reprogramming in the germ line. Epigenetics. 2008; 3:5-13. [PubMed: 18259118]

$110^{* *}$. Reik W, Dean W, Walter J. Epigenetic reprogramming in mammalian development. Science. 2001; 293:1089-1093. [PubMed: 11498579] [Critical review of the developmental epigenetic programming of DNA methylation in the early embryo and fetal germline.]

111. Allegrucci C, Thurston A, Lucas E, Young L. Epigenetics and the germline. Reproduction. 2005; 129:137-149. [PubMed: 15695608]

112. Durcova-Hills G, Hajkova P, Sullivan S, Barton S, Surani MA, McLaren A. Influence of sex chromosome constitution on the genomic imprinting of germ cells. Proc Natl Acad Sci U S A. 2006; 103:11184-11188. [PubMed: 16847261]

113. Jirtle RL, Skinner MK. Environmental epigenomics and disease susceptibility. Nat Rev Genet. 2007; 8:253-262. [PubMed: 17363974]

114. Clement TM, Anway MD, Uzumcu M, Skinner MK. Regulation of the gonadal transcriptome during sex determination and testis morphogenesis: comparative candidate genes. Reproduction. 2007; 134:455-472. [PubMed: 17709564]

115. Clement TM, Savenkova MI, Settles M, Anway MD, Skinner MK. Alterations in the developing testis transcriptome following embryonic vinclozolin exposure. Reprod Toxicol. 2010; 30:353364. [PubMed: 20566332]

116. Anway MD, Rekow SS, Skinner MK. Transgenerational epigenetic programming of the embryonic testis transcriptome. Genomics. 2008; 91:30-40. [PubMed: 18042343]

117. Skinner M, Guerrero-Bosagna C, Haque MM, Nilsson E, Bhandari R, McCarrey J. Environmentally Induced Transgenerational Epigenetic Reprogramming of Primordial Germ Cells and Subsequent Germline. PLoS ONE. 2013; 8:e66318. [PubMed: 23869203]

118. Skinner MK, Manikkam M, Haque MM, Zhang B, Savenkova M. Epigenetic Transgenerational Inheritance of Somatic Transcriptomes and Epigenetic Control Regions. Genome Biol. 2012; 13:R91. [PubMed: 23034163] 
Epigenetic Transgenerational Inheritance of Male Infertility

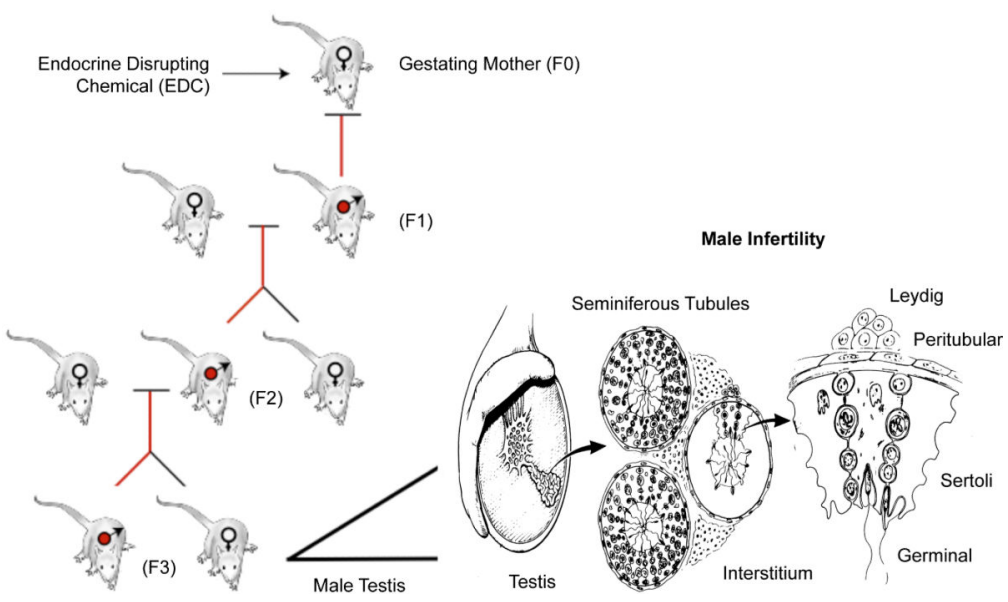

Figure 1.

Epigenetic transgenerational inheritance of male infertility. The environmental actions on an F0 generation gestating female reprograms the germline epigenome to promote a transgenerational event through the male germline in the absence of exposure for four (F4) generations. The testis morphology shown demonstrates the cooperation of somatic cells and spermatogenic cells in the process. 


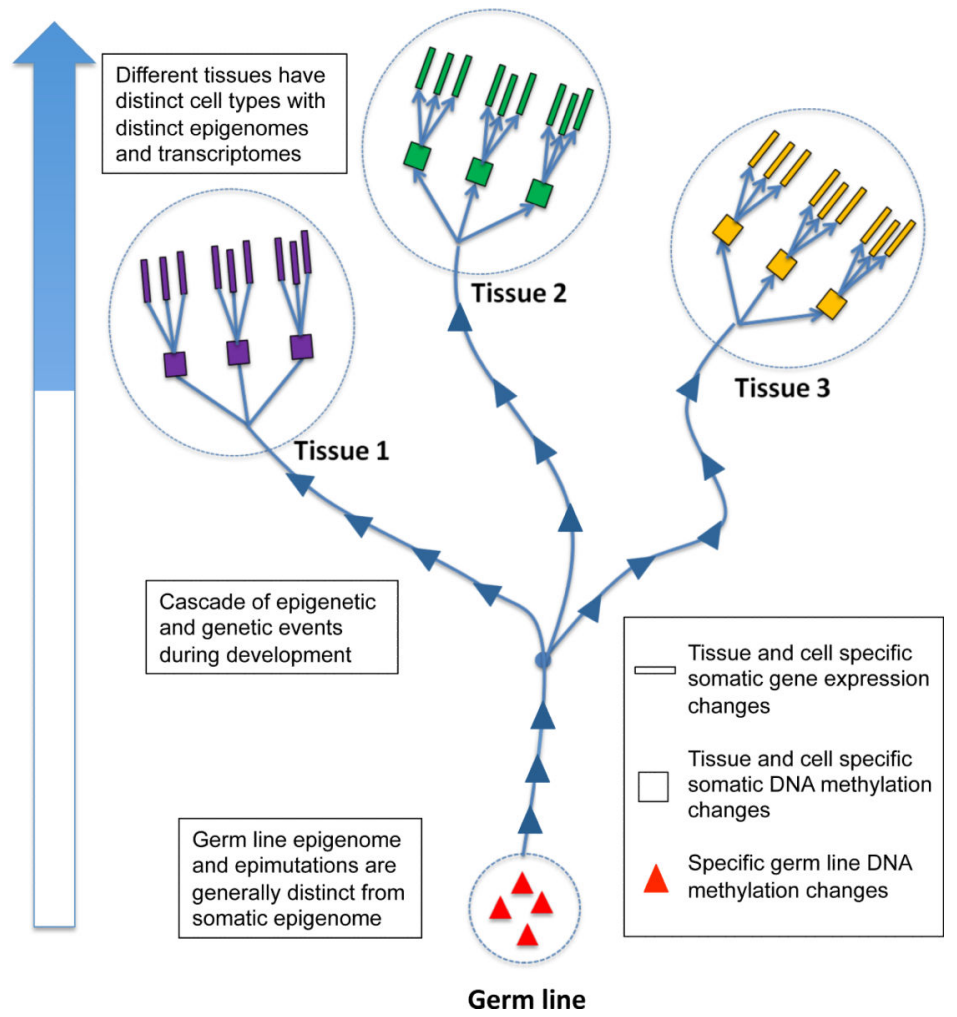

Figure 2.

Schematic representation of environmentally-induced germline epigenome modifications and further epigenomic and transcriptomic effects in somatic cells that are distinct between tissues and cell types. 


\section{Table 1}

Categorization of the causes of impaired fertility

\begin{tabular}{|c|c|c|c|}
\hline Causes & Description & Examples & References \\
\hline Genetic & $\begin{array}{l}\text { Genetic abnormalities that } \\
\text { associate with impaired } \\
\text { fertility parameters }\end{array}$ & $\begin{array}{l}\text { Aneuploidies of the sex } \\
\text { chromosome; Mutations (e.g. genes } \\
\text { Cftr, Fsh beta, Nr5a1, Art3, Ddrl, } \\
\text { Usp8, Prmt6, Pex10, Sox5 Slc6a14, } \\
\text { Insr, Or3w3); Deletions (e.g. Azfc } \\
\text { region, genes Fkbp6, Ppp1cc2) }\end{array}$ & {$[34,36-42,44]$} \\
\hline Epigenetic & $\begin{array}{l}\text { Environmental exposures } \\
\text { anytime during the life of the } \\
\text { individual that are associated } \\
\text { with epigenetic alterations and } \\
\text { impaired fertility parameters }\end{array}$ & $\begin{array}{l}\text { Adult exposures to butyl-paraben or } \\
\text { methoxychlor; Neonatal exposure to } \\
\text { BPA; Prenatal exposure to ethanol }\end{array}$ & {$[72,73,76,77]$} \\
\hline Epigenetic Transgenerational Inheritance & $\begin{array}{l}\text { Impaired fertility parameters } \\
\text { are triggered by germ line } \\
\text { epimutations produced as } \\
\text { result of ancestral } \\
\text { environmental exposures }\end{array}$ & $\begin{array}{l}\text { Early developmental exposure to } \\
\text { environmental toxicants (e.g. } \\
\text { vinclozolin, BPA, phthalates, DDT } \\
\text { or methoxychlor) that produce } \\
\text { alterations in sperm DNA } \\
\text { methylation }\end{array}$ & $\begin{array}{l}{[73,74,78,79} \\
90,92,93]\end{array}$ \\
\hline Life style practices/Occupational exposures & $\begin{array}{l}\text { Chronic adult daily practices } \\
\text { or exposures that are } \\
\text { detrimental to reproductive } \\
\text { parameters but potentially } \\
\text { reversible }\end{array}$ & $\begin{array}{l}\text { Constant scrotum overheating (e.g. } \\
\text { hot baths); obesity; smoking; use of } \\
\text { marihuana or cocaine; exposure to } \\
\text { insecticides, pesticides or organic } \\
\text { pollutants }\end{array}$ & {$[2,11]$} \\
\hline
\end{tabular}

